\title{
THE ROLE OF ADVANCED LEARNING TECHNOLOGIES IN PROFESSIONAL TRAINING OF FUTURE PHILOLOGISTS AT US UNIVERSITIES
}

Summary. The paper analyzes the main forms, methods and technologies in professional training of future philologists at US universities. It highlights the main (inductive, deductive and functional) approaches that form the basis of professional training of future philologists. It describes the advantages of e-learning and blended learning models in professional training of future philologists. It discloses the specifics of using interactive and reflexive learning methods in the US education system. It also focuses on the use of information and communication technologies and multimedia learning. It concludes that these technologies effectively influence the process of developing professional competences in future philologists. Further research should aim to study the diagnostics tools for developing professional competency in philology students at US universities.

Keywords: philologist, training models, interactive methods and technologies, multimedia, the USA.

Іконнікова М.В.

Хмельницький національний університет

\section{РОЛЬ НОВІТНІХ ОСВІТНІХ ТЕХНОЛОГІЙ У ПРОФЕСІЙНІЙ ПІДГОТОВЦІ МАЙБУТНІХ ФІЛОЛОГІВ В УНІВЕРСИТЕТАХ США}

\begin{abstract}
Анотація. У статті проаналізовано основні фрорми, методи і технології профресійної підготовки фрілологів в університетах США. У системі вищої філологічної освіти в США за останні роки відбувся конструктивний перерозподіл фрункцій між студентами та викладачами. Студенти посіли центральне місце у навчальному процесі: вони отримали змогу самостійно обирати зміст та методи навчання, визначати послідовність засвоення навчального матеріалу. Викладачі взяли на себе фрункцї тьюторів, які спрямовують студентів до джерел фактичної інформащії. Інтенсивне впровадження інформаційних технологій в американському освітньому середовищі зумовило використання традиційної (відбувається очний контакт між студентами та викладачем), електронної та змішаної моделей навчання. Електронна модель охоплюе усі форми комп'ютерно-фасилітованого аудиторного або самостійного (синхронного, асинхронного) навчання із застосуванням інформаційно-комунікаційних технологій: у режимі «он-лайн», за допомогою локальних комп'ютерних мереж, віртуальних аудиторій, цифрових засобів навчання. Змішане навчання поєднує традищійні та Інтернет-орієнтовані технології, що одночасно задовольняе потреби студентів в очній та інтерактивній комунікації. Вивчення теоретичного та практичного досвіду підготовки фрілологів в університетах США показало, що організація навчання таких фахівців здійснюеться на основі трьох підходів: індуктивного, дедуктивного та функціонального. Індуктивний підхід полягає в опрацюванні попередньо підібраних викладачем текстових матеріалів. Дедуктивний підхід передбачає оволодіння технікою аналізу окремих мовних та літературних явищ. Функціональний підхід оріентуеться на фрормування системи навичок профресійної діяльності. Використання IКТ у навчанні фрілологів сприяе поглибленню лінгвістичних знань; підвищенню рівня культурної компетенції; формуванню дослідницьких навичок; удосконаленню техніки перекладу; ознайомленню з професійними аспектами перекладацької діяльності; фрормуванню навичок редагування перекладів та забезпечення якості перекладацьких послуг; набуттю умінь координувати перекладацькі проекти, працювати у команді; формуванню навичок роботи 3 термінологічними базами; стимулюванню автономного навчання та самооцінюванню. Серед освітніх пріоритетів визначено мультимедійні технології, які допомагають інтегрувати й розширювати навчальну інформацію завдяки графічним, анімаційним, відео та звуковим ресурсам. З'ясовано, що організація якісної професійної підготовки фрілологів в університетах США передбачає використання сучасних інноваційних фрорм, методів і технологій навчання.
\end{abstract}

Ключові слова: філолог, організація навчання, моделі навчання, інтерактивні методи і технології, медіазасоби, США.

$\mathrm{P}$ roblem statement. Nowadays, US universities strive to optimize the educational process in the context of philological education, given the rapid development of information and communication technologies. They assure the quality of professional training of future philologists based on scientifically justified methods, taking into account the principles of philosophy, psychology, cognitive linguistics, media pedagogy, applied linguistics. In recent years, the system of philological education at US universities has witnessed a constructive redistribution of functions between students and university teachers. Nowadays, students are central to the educational process since they can inde- pendently choose the content and methods of learning, as well as determine a pattern of mastering educational material. University teachers act as tutors, who assist students in finding relevant information and motivate them towards autonomous learning. This is facilitated by a diverse range of learning forms, methods and technologies.

Analysis of recent studies and findings. Ukrainian and foreign researchers have also paid much attention to the problem of professional training of philologists (L. Bazyl, N. Bidiuk, S. Danyliuk, P. Kastberg, W. Lewis, O. Martyniuk, R. Moore, W. Neuman, V. Santibanez, O. Semenoh, L. Tomei, O. Zinovatna et al.). Despite many studies on this 
particular problem, it is essential to reveal procedural and technological aspects of professional training of philologists at US universities.

The paper aims to disclose the procedural principles of professional training of future philologists in the US higher education system.

Results. The rapid introduction of information technologies in the educational environment of US universities has led to the use of traditional (face-to-face communication between students and university teachers), electronic (e-learning) and blended (b-learning) learning models. One should pay particular attention to e-learning and blended learning. E-learning covers all forms of computer-assisted teaching and learning in classrooms or autonomous (synchronous, asynchronous) learning using information and communication technologies: online learning technologies, local computer networks, virtual audiences, digital learning tools. This model is most effectively used in distance learning of future philologists. Blended learning combines traditional and Internet technologies, thus meeting the needs of students for face-to-face and interactive communication. The advantages of such a model as compared to a traditional one include asynchronous learning, regardless of learners' location, as well as the possibility of effective adaptation of learning forms to their individual needs. A vast array of information is presented through a combination of traditional and hypertext resources with multimedia tools (sounds, videos, hyperlinks). It allows philology students to choose a pattern of processing information sources and work with materials containing contradictory views on solutions to certain problems. Local and global information networks facilitate the exchange of information between the participants in the educational process, as well as contribute to active discussion of problematic issues at any convenient time for them.

Taking into account the characteristics of each model, they incorporate different teaching and learning forms (classes: lectures, practical classes, seminars, laboratory work, one-to-one tuition, consultations), independent work, practical training, assessment), methods and technologies. In the context of future philologists' professional training, the most popular are the following: traditional lectures, debate lectures, consultations and lectures, lecture presentations [7;8]. These lectures revitalize the educational process, provide feedback between university teachers and students, facilitate an exchange of views, stimulate students' cognitive activity and develop their critical thinking. Practical classes and seminars help to develop students' professional skills and competences within the framework of the curriculum. They include performing and checking practical tasks, discussing mistakes, suggesting ways to solve certain problems, comparing and evaluating the obtained results.

According to N. Bidiuk, the concept of philological education in international experience is implemented through interactive and reflexive forms and methods of teaching and learning, including discussions in micro-groups, asynchronous discussions, project-based learning, visualization, brainstorming, semantic graphs, mind maps, chain association methods, simulations, successful situa- tions, discovery-based learning. Besides, university teachers use the following innovative methods to develop philology students' professional competency: research-led teaching, research-oriented teaching, research-based teaching, research-informed teaching, research-tutored teaching. They are aimed at developing philology students' research skills, analytical and critical thinking, motivating them towards scientific discussion and shaping their scientific outlook [1, pp. 110-111; 2].

The analysis of US theoretical and practical experience in training future philologists shows that such training is based on inductive, deductive and functional approaches. An inductive approach implies working on the texts chosen by the teacher, who checks and corrects students' mistakes, as well as discusses these mistakes with them. Based on such materials, teachers can offer some recommendations so that students can solve these or other problems and summarize students' results. Texts are chosen based on such criteria as topics, genres and complexity. The complexity of such texts can be determined by their lexical content (the amount of specialized terminology), structure (the linguistic discourse) and cultural load (the divergence of communication traditions). The advantage of this approach is "the realism" of linguistic problems since they are viewed in a holistic context. It helps to approximate learning to professional activities. $A$ deductive approach teaches students to analyze particular linguistic and literary phenomena. The teacher needs to identify the main problems and select learning materials illustrating these problems properly. The difficulty lies in searching for coherent texts, not isolated from the context of sentences since working with individual sentences is considered ineffective from a methodological point of view. The list of problems is formed based on the results of comparative linguistic studies (differences between source and target languages), comparative linguistics (differences between texts of source and target languages, including marking the beginning and the end of the discourse, temporal and spatial relations, logical relationships between events, identifying event participants, semantic emphasis, author's notes), techniques for translating lexical units (borrowing, loan translation, literal translation, transposition (using one language form as a function of another), modulation, adaptation). The advantage of this approach means one's ability to cover a wide range of language and literary issues. Its disadvantage is the use of small (often no more than one or two sentences) unrelated excerpts of texts to address a particular issue, while a professional linguist works with larger, more structured materials. A functional approach focuses on elaborating a system of professional skills. University teachers determine what skills students need to develop and direct the educational process towards the set goal. Indeed, one can learn how to move away from a certain linguistic form with the help of native-language transformations (paraphrases) in the source or target languages. Those skills which philology students need to define the main idea of the text can be developed by searching for keywords, abstracting. The advantage of this approach is its focus on the system of future specialists' practical skills. Its disadvantage, however, 
is students' unwillingness to solve important language problems, which are taken into account by a deductive approach [4, p. 89].

Some US universities consider it important to use socio-pedagogical approaches (personal knowledge management and qualitative and quantitative approach) in professional training of future philologists $[3 ; 6]$. They are especially effective for developing key competences.

One can promote students' cognitive activity using the method of modelling real professional situations (for example, teamwork, time-limited tasks), the gaming method (role-playing games during which students perform different roles), brainstorming (a group creativity technique by which efforts are made to solve certain problems), analyzing particular situations (real examples from translation practice are considered), round-table discussions (discussing and analyzing students' reports), the method of trial and error [10].

Laboratory work is an important form of professional training of future philologists. It takes place in specialized linguistic laboratories (PC labs, laptops, loan service) equipped with high-quality technical tools and technologies. In addition to audio and video equipment, computer technologies, philology students can work with the latest software such as "language partner" and "language evaluator", online glossaries and databases. It allows them to analyze their pronunciation, identify errors and ways to correct them, focus on significant errors with the help of their value indicator, watch recorded videos and discuss them with their teachers. Also, university teachers can create databases of short videos on different topics, simulate real communication and engage in interactive dialogues. One of the components of professional training of future philologists is the development of Internet skills. Philology students search for and process materials (catalogues of products, specifications, instructions, research papers) in a foreign language, develop websites and order the necessary educational literature. E-mails allow them to communicate with their teachers, send them papers for review and receive results with all necessary corrections and comments. The most productive ones are electronic lectures, textbooks, encyclopaedias, dictionaries, 3D panorama, situational role-playing and intellectual games using artificial intelligence, teleconferences, virtual tours, programmed tests, presentations, videos, social networks (Facebook, Twitter, Skype, Myspace, Hi5, Bebo, MSN).

University facilities provide students with access to innovative information and communication technologies (p-HInT, Instructional Kitchen Studio (IKS), PROPEL, IdeaBoard, WWW E-TCL, CodEx, WebICL, PROMASTER, DLNRS). At the same time, these technologies act as learning tools since they ensure the process of cognition and assist philology students in creating their professional styles, develop their critical thinking and research skills), as the subject of learning (both the knowl- edge and practical use of modern methods for processing data, which are required in the professional environment) and as a tool for solving professional problems (developing decision-making skills). Philology students master profession-oriented courses based on such licensed programmes, languages and technologies (Java, C\#, F\#, Python, .NET, SQL, CSS, HTML, PHP, Javascript, Prolog, LISP, Rational Software Architect), MySQL, MS SQL SERVER, ORACLE, Sybase Power Designer, MS Visio, IBM DB2, AllFusion ERwin Data Modeler, Eclipse 3.5 (Galileo), GRID) [5; 9].

The use of information and communication technologies (quizzes, chats, wikis, forums, glossaries) in professional training of future philologists contributes to deepening linguistic knowledge, increasing the level of cultural competency, enhancing research skills, improving translation techniques, highlighting professional aspects of translation (performing time-limited tasks, communication with customers), developing translation editing skills, translation projects coordination skills, teamwork skills and motivating towards autonomous learning and self-assessment.

Educational priorities are about multimedia technologies that help integrate and expand learning information due to graphic, animation, video and audio resources. Particularly important is the concurrent presentation of visual and audio information, which improves its perception by future philologists. Given that multimedia technologies are based on the principle of visualization, they can improve the process of memorizing new educational material, widen the opportunities for training the phonetics of a foreign language by listening to audios and videos on educational material narrated by native speakers and assist philology students in overcome language barriers. Besides, they provide access to authentic demonstrations and presentations of educational material available on the Internet, stimulate the active acquisition of a foreign language through free and daily access to foreign-language online dictionaries, encyclopaedias, versions of online magazines and newspapers, diversify independent research activities and search for educational information and intensify the educational process.

Conclusions and prospects. Therefore, high-quality professional training of future philologists at US universities is organized based on the use of innovative forms, methods and technologies of teaching and learning. It much contributes to developing philology students' cognitive and creative activities and professional competences, facilitating the interaction between the participants in the educational process and creating a profession-oriented environment. The use of innovative ideas of US experience can help to improve the didactic and methodological principles of professional training of future philologists in Ukrainian education.

Further research should aim to study the diagnostics tools for developing professional competency in philology students at US universities. 


\section{References:}

1. Bidyuk, N.M. (2013). Kontseptualni zasady profesiinoi pidhotovky fakhivtsiv z prykladnoi linhvistyky u SShA [The Conceptual Principles of Professional Training of Specialists in Applied Linguistics in the United States]. Porivnialna profesiina pedahohika, 2, 105-116.

2. Bidyuk, N.M. (2013). Yevropeiski oriientyry v obgruntuvanni kontseptualnykh zasad profesiinoi inshomovnoi osvity [European Guidelines for Justifying the Conceptual Principles of Professional Foreign-Language Education]. In V. H. Kremen (Ed.), Edukacja dla współczesności, vol. 2, pp. 390-399. Kyiv: M.P. Drahomanov National Pedagogical University.

3. Agnihotri, R. (2009). The Effective Use of Technology in Personal Knowledge Management: A Framework of Skills, Tools and User Context. Online Information Review, 33(2), 329-342.

4. Kastberg, P. (2009). Personal Knowledge Management in the Training of Non-Literary Translators. The Journal of Specialized Translation, 11, 88-101.

5. Moore, R.C., \& Lewis, W. (2010). Intelligent Selection of Language Model Training Data. Proceedings of the ACL 2010 Conference. Stroudsburg, PA: Association for Computational Linguistics.

6. Neuman, W.L. (2011). Social Research Methods: Qualitative and Quantitative Approaches. Boston, MA: Pearson.

7. Santibanez, V.E. (n.a.). Advanced Translator Training in the United States. Retrieved from: https:// isg.urv.es/ $\mathrm{cttt} / \mathrm{cttt} / \mathrm{research} / \mathrm{santibáñez.doc}$

8. Shearer, R.L. (n.a.). Classroom Design for Video Teleconferencing. Retrieved from: http://www.ncef.org/rl/ Community_Colleges.cfm

9. Tomei, L.A. (2010). Online Courses and ICT in Education: Emerging Practices and Applications. Hershey, PA: IGI Global.

10. Weisberg, H.F. (2005). The Total Survey Error Approach: A Guide to the New Science of Survey Research. Chicago, IL: University of Chicago Press. 